\title{
Log Transport in the Limestone Alps, Austria: Where Did the Timber Go?
}

\author{
Michael Grabner | ORCID 0000-0002-5220-721X \\ University of Natural Resources and Life Sciences - во KU, Vienna, Institute \\ of Wood Technology and Renewable Resources, Uft Tulln, Konrad Lorenz \\ Strasse 24, 3430 Tulln, Austria \\ michael.grabner@boku.ac.at \\ Elisabeth Wächter \\ University of Natural Resources and Life Sciences - вокU, Vienna, Institute \\ of Wood Technology and Renewable Resources, UfT Tulln, Konrad Lorenz \\ Strasse 24, 3430 Tulln, Austria \\ elisabeth.waechter@boku.ac.at
}

\author{
Sandra Karanitsch-Ackerl \\ University of Natural Resources and Life Sciences - вокU, Vienna, Institute \\ of Wood Technology and Renewable Resources, UFT Tulln, Konrad Lorenz \\ Strasse 24, 3430 Tulln, Austria \\ sandra.karanitsch@boku.ac.at
}

Markus Jeitler | ORCID 0000-0001-9255-534

Faulmanngasse 5/7, 1040 Vienna, Austria

markus.jeitlerı@chello.at

Günther Buchinger | ORCID 0000-0003-4989-2049

Denkmalforscher GesBR, Margaretenstraße 82/22, 1050 Vienna, Austria guenther.buchinger@denkmalforscher.at

\footnotetext{
Abstract

Wood is one of the most important sustainable natural resources. Throughout centuries, large cities as well as regions of very high wood demand (for example, areas of salt production and iron processing) had to be supplied with wood for building and burning. One of the largest forests in Austria can be found in the National Park covering 
the range of mountains called "Limestone Alps." Within this region, a wide network of dams was set up to transport single logs ("Holztrift"). Due to the dendrochronological dating of the surviving dams, regional chronologies spanning a length of almost 6 oo years for Norway spruce, Silver fir and European larch were set up. These chronologies serve as the background for dendro-provenancing timber. Dendro-provenancing checks the similarities between samples and different regional chronologies. The highest statistical figures give hints of the origins of the wood. Archival analyses show that many logs were transported to Vienna as rafts. For example, in 1865, more than 1504 rafts arrived in Vienna, all from different origins. The logs were used as building material as well as for burning. Further archival analyses showed that logs from this region were also used for building the roof of the Hofburg Castle in Vienna. Several hundred samples from the roof construction were dendrochronologically dated and used for dendro-provenancing. The origin of the logs was confirmed to be the wider region of the Northern alpine foothills. This meant that rafts from the rivers Alm and Traun as well as from the rivers Steyr and Enns had floated down to Vienna.

\section{Keywords}

wood utilization - wood supply - transport of wood - dendrochronology - dendroprovenancing

\section{Introduction}

Wood was, and still is, one of the most important multi-purpose and sustainable natural raw materials. It surrounds us from the cradle to the grave. The products vary from toys, tools, housing and fuel to works of art and religious objects (Begemann 1977, Ziethen 2000, Radkau 2007, Wegener 2007). While the cultural history of wood utilization has not been completely written, it is evident that the cultural activity of human beings has always been strongly linked to wood.

Since ancient times, wood has primarily been used as burning material (fire wood and charcoal) and construction timber (mainly for house building). There were many different regions where there was a high demand for wood in Austria - on one hand, places where goods were manufactured (such as salt, glass and metal implements) and on the other hand, cities with a high demand of both construction and burning material (see Fig. 1).

Von Keeß $(1823,5)$, for example, calculated the demand for fuel wood for the city of Vienna (Austria) at 814 ooo cubic meters (240 ooo klafter) in the 


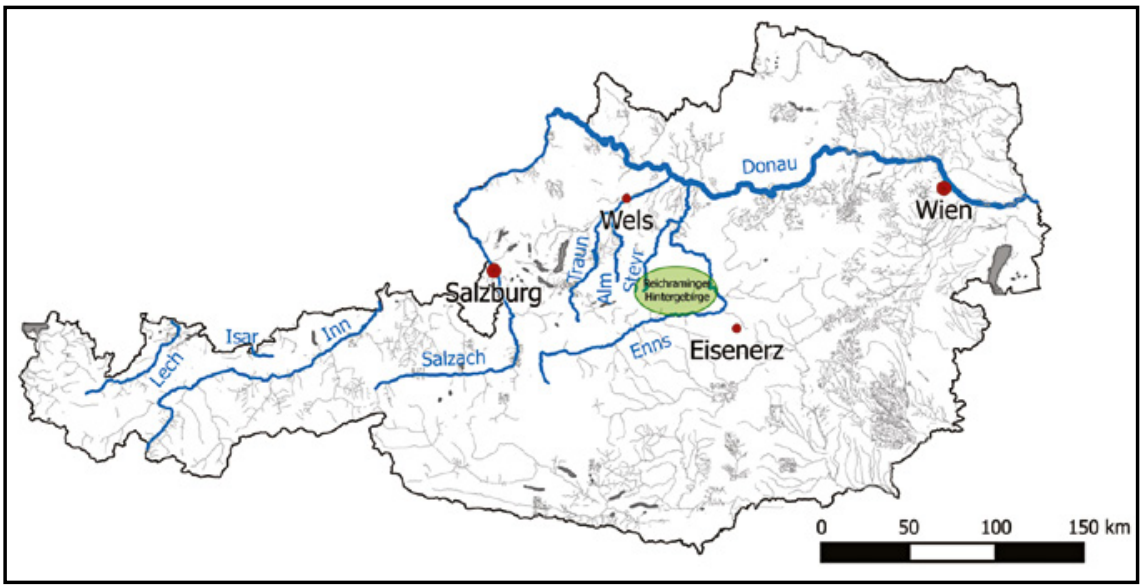

FIGURE 1 Map of Austria presenting some places of high demand on wood (Eisenerz, Wien, Salzburg), places of interest (National Park Limestone - Reichraminger Hintergebirge, city of Wels) and the most important rivers relevant for the transport of timber to Vienna.

beginning of the 19th century. Neweklowsy $(1964,531)$ estimated the volume consumed in the year 1840 to have been anywhere between 1.3 and 1.7 million $\mathrm{m}^{3}$. This figure in the year 1870 decreased by 470 ooo to $540000 \mathrm{~m}^{3}$. The reason for this decline was that a greater amount of coal was burned and wood was used more sparsely for burning that year.

For centuries, the smelting and processing of iron has been a key factor in the economic development of certain areas. In Austria, the exploitation of iron ore took place in the area of Eisenerz, in Styria, about $70 \mathrm{~km}$ from the Reichraminger Hintergebirge. The utilization of this important raw material was under governmental control, since enormous amounts of burning material were necessary for smelting iron. As mineral coal was not available, charcoal was used instead. A great portion of forestlands of the Eisenerz region was harnessed to produce charcoal.

Consequently, smelting and further processing of iron had to be geographically dispersed due to lack of wood for producing charcoal (see Fig. 1). Therefore, the iron-processing industry settled down along the trade routes of the rivers Enns and Steyr.

In $1583 \mathrm{AD}$, the register of the governance of Steyr recorded 24 forges. Along the rivers Enns and Steyr, 40 forges were producing scythes in the 16th century (Weichenberger 1994, 7). Due to the huge demand for charcoal, the remote forests of the Reichraminger Hintergebirge located in the Northern Limestone Alps, Upper Austria, had to be utilized. As there were no ox-paths, it was easier 
to transport logs than charcoal. To bridge the long distances from felling sites to the bigger rivers, all logs were transported on small rivers.

What happened there? Were all logs used to produce charcoal? How much of the timber was used for construction material? And where did the timber go?

\section{$2 \quad$ Transport of Single Logs - "Trift"}

Burning material was to be transported, and it was even more complicated to supply construction material to places of high demand, such as the cities. All historical cities (such as Vienna, Krems, Salzburg) were located next to rivers. These rivers were obviously used for transport of logs and timber (Neweklowsky 1952, 541-624; Koller 1954, 16; Neweklowsky 1959, 131-138; Wiesenhofer and Wiesenhofer 2015, 4).

The German terms "Trift" and "Schwemme" describe the transport of individual water-borne logs. This kind of transport was common in the alpine regions of Austria. When the forests close to the bigger rivers were depleted, new resources were harvested and the logs were transported with the help of smaller rivers (Neweklowsky 1960, 169). Wood for burning or to produce charcoal (1-2 m long) and logs for saw-mills (up to $6 \mathrm{~m}$ ), as well as much longer logs were transported this way (Neweklowsky 1960, 170). The regions in Austria that were producing salt had huge systems of log transport in place. The areas of salt production in the "Salzkammergut" in Upper Austria required a system of 75 dams and 25 rakes to transport sufficient amounts of burning wood (Neweklowsky 1960, 174). The iron processing industry used charcoal, which was produced close to the rakes. At Großreifling in Styria, Austria, 11 kilns were known to produce over 25.8 cubic meters of charcoal per year. The salt production in Hallein (Salzburg, Austria) used coal as its heating material in 1870 because of the increase in prices of fire-wood (Neweklowsky 1960, 173). The single-log transportation ("Trift") of long logs for construction purposes was confined to the rivers Steyr and Alm (Upper Austria, see later; Neweklowsky 1960, 176).

The Reichraminger Hintergebirge - one of the biggest forested areas in Austria - is located in the Limestone Alps. Its narrow valleys and low water depth were considered unsuitable for log transportation. To raise the water 
level temporarily, splash dams ("Klausen") were built to manage the flow of water downstream. These splash dams were complex constructions of logs and stones, and they were built using wood harvested from immediate surroundings (Neweklowsky 1960, 171).

The procedure for the "Trift" was as follows (Neweklowsky 1960, 171): numerous logs were placed below the dam and the water storage area was filled with water from melting snow or heavy summer storms. A flood wave - induced by an abrupt opening of the flood-gates - had enough power to drift the logs downstream. A system of up to 7 "Klausen" was built, which connected the innermost forests to the "Rechen" installed (rake-like grids within a river to collect the logs) approximately $12 \mathrm{kms}$ away in the rivers of Enns and Steyr. When the opening of the floodgates of each "Klause" was properly synchronized, logs could be transport over the entire distance within an hour. The Reichraminger Hintergebirge, which is now a part of the Limestone Alps National Park, once had the highest density of "Klausen" in all of central Europe.

The biggest and most impressive dam was the Mitterwendt Klause (Grosse Klause), which was known to be $20 \mathrm{~m}$ in height. It was first mentioned in $1604 \mathrm{AD}$ in the forest regulations of Rudolf II. It was possible, by using this dam system, to transport vast amounts of logs within short periods of time. Beech (Fagus sylvatica L.) was not used for water-borne log transportation, owing to its high wood density. Norway spruce (Picea abies L. Karst) was favored instead. The "Trift" ceased shortly before World War II, as a consequence of high mineral coal being imported and the growing availability of forest roads.

Before the Reichraminger Hintergebirge region was turned into a National Park, historians had already started to reconstruct the forest utilization history of the area. One can find calendar dates that indicate the construction of the "Klausen" by searching registers, forest regulations and archives. A majority of the splash dams were mentioned in regulations (e.g., those by Rudolf II in $1604 \mathrm{AD}$ ). Although this documentary evidence provides proof of the existence of "Klausen" at certain times, it lacks information on the actual year of construction. Furthermore, it is not known how long certain drifting constructions and dams had been in use before they were abandoned.

To reconstruct the history of log transportation in the Reichraminger Hintergebirge, 33 "Klausen" and other buildings were dendrochronologically dated (Grabner et al. 2004, 134). The remaining wood of the dam constructions showed signs of progressive stages of degradation and in some cases only a few logs remained preserved under water. The construction history of the "Klausen" can be sequentially traced back to $1563 \mathrm{AD}$. The youngest timber found has been dated back to $1924 \mathrm{AD}$. With cores from living trees added to 
the dataset, master chronologies were established for spruce ( 576 years), fir (569 years), and larch (342 years), respectively.

What happened with the logs at the rivers Enns and Steyr? Were they all converted to charcoal or were they transported as rafts to big cities?

Floating or rafting (in German "flößen" or "Flößereiwesen") describes the transport of rafts built out of logs, which were tied with ropes or some ropelike material such as withies (see figure 2; Neweklowsky 1960, 169-170). To set up these rafts, many thousands of logs (usually the long ones) were bound together with the help of rope-like withies (specially prepared small stems or long branches; Keweloh 1985, 67). Then, different kinds of wedges were used to fix these withies (Neweklowsky in 1952, Tafel x to XVII). These floats (or rafts) were used for long-distance transportation of logs (for example, Jägerschmid 1827, 2; Sponeck 1825, 12-13; Neweklowsky 1952, 541-542; Neweklowsky 1959, 131; Delfs 1985, 34-36).

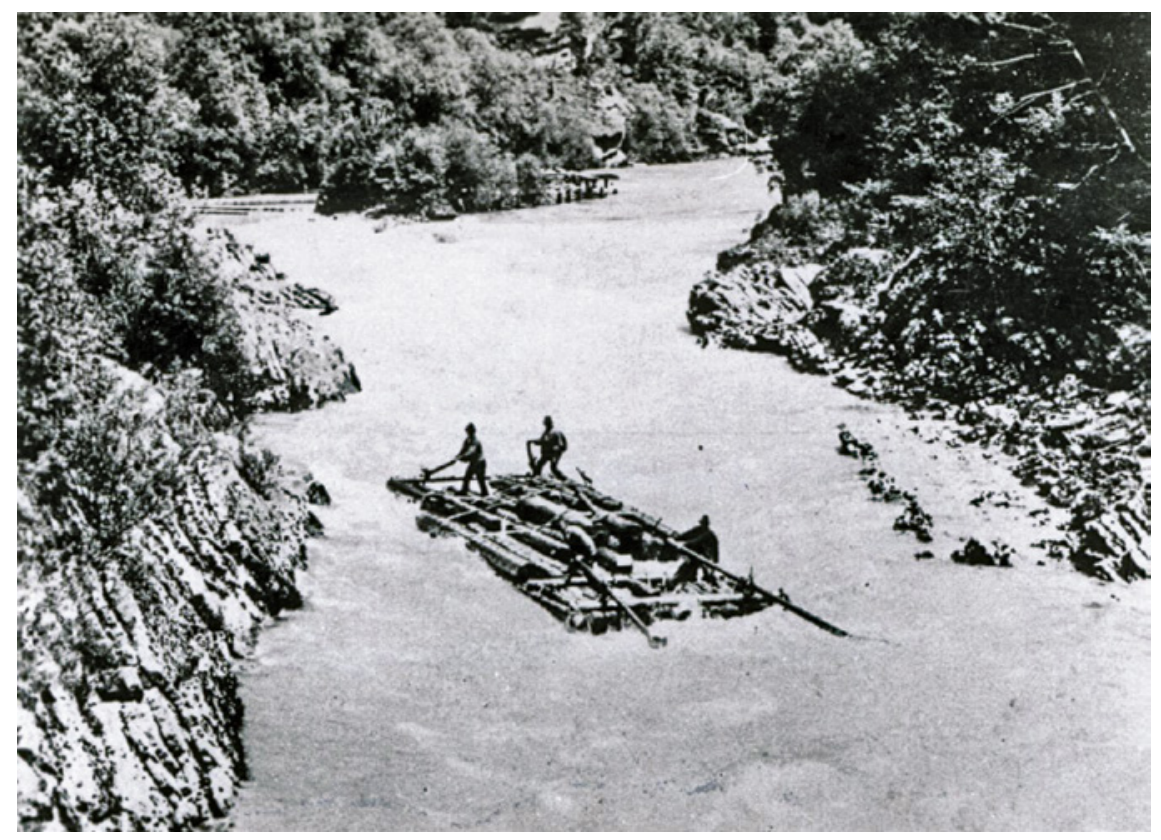

FIGURE 2 A raft at the river Enns (Forstliche Bundesversuchsanstalt 378-4). 
The long logs (for construction purposes) were sent down to bigger rivers (like Enns, Steyr, Alm and Traun) to bind them to rafts. Often, they floated to the Danube, where huge rafts were built out of many of the smaller rafts. At the rive of Rhine, these rafts were up to $400 \mathrm{~m}$ in length, $80 \mathrm{~m}$ in width and 5 meter in height - or about 12.000 cubic meters per raft (Delfs 1985, 43). Very often they were built to transport iron ore or stones. Between 1623 and 1860, it was even possible for passengers to travel in these rafts from Munich (Germany) to Vienna (Austria) and even all the way up to Budapest (Hungary) once a week (Keweloh 1985, 101). The importance of log transport - the single log floating, as well as the rafts - was mentioned for the first time in the 13th century. Neweklowsky $(1952,588)$ reported about 40 rafts starting at the small river Alm (1825) and about 1504 rafts arriving in Vienna on the Danube in the year of 1865 .

The Vienna Castle (Hofburg) was the domicile of the Habsburgs for over eight centuries and very much the center of European politics. During this time, a lot of construction timber was used to set up various parts of the building, especially the roof and ceilings. Since 2006, 518 samples from the roof of the Hofburg Castle have been taken. Close to 425 of these samples could be dated and were studied for further analysis. The dates of the bark ring (Waldkante), i.e. the outermost ring below the bark (representing the felling of the tree), varied from $1347 \mathrm{AD}$ to $1922 \mathrm{AD}$. Intense phases of construction have been determined. The tree rings of timber can not only date the construction phases of Hofburg but also give an indication of its origin (dendro-provenancing).

In dendrochronology, the similarities between the tree-ring patterns of samples and chronologies are used for dating (for example, Bailie 1995). An analysis of the similarities between samples and regional chronologies within a small region, for example, the Reichraminger Hintergebirge, could determine the origin of logs (Daly 2007, Eckstein and Wrobel 2007, Eißing and Dittmar 2011). Drawing from the analyses conducted by Thomas Eißing in Germany and pertinent literature on the subject (for example, Neweklowsky 1952, 1959), it is known that almost all the small rivers joining the Danube were used to transport logs as rafts (e.g., Lech, Isar, Inn, Salzach, Große Mühl, Traun, Steyr and Enns; see Fig. 1). These rivers facilitated the utilization of vast forest-lands. Logs and timber were transported to Vienna in rafts and further on to Hungary.

In the wooden roof constructions (see Fig. 3 for an example of the Amalienburg) of the Vienna Hofburg, rafting wedges were found (see Fig. 4 for 


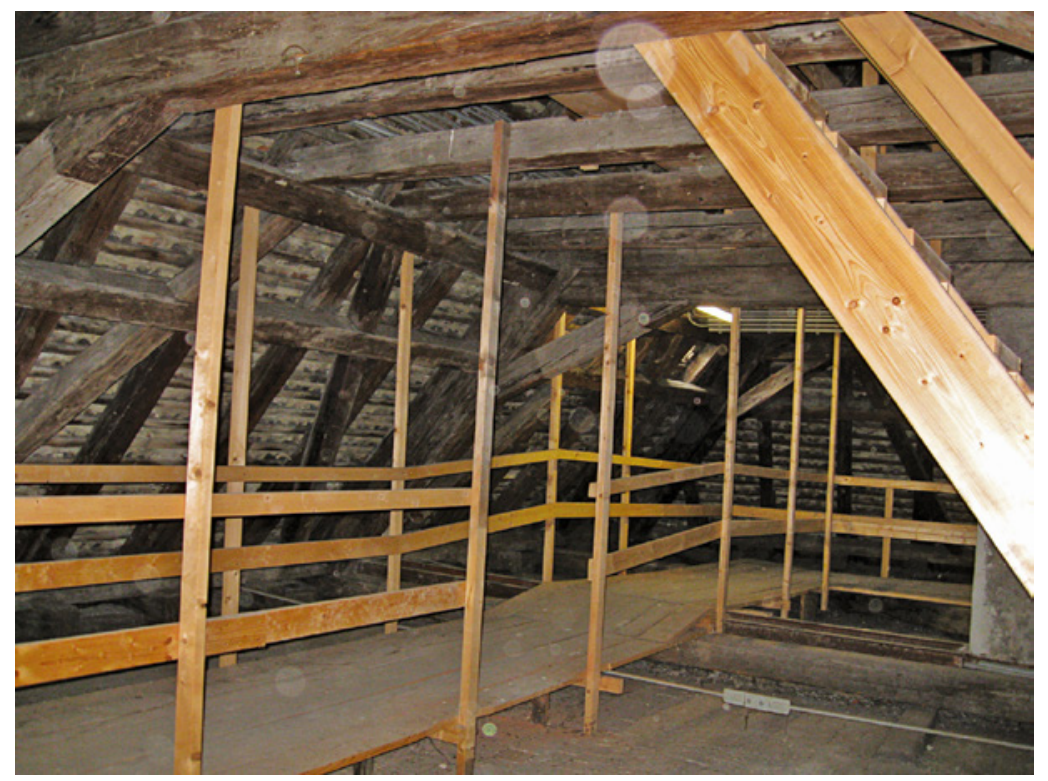

FIgURE 3 A part of the roof construction of the Amalienburg.

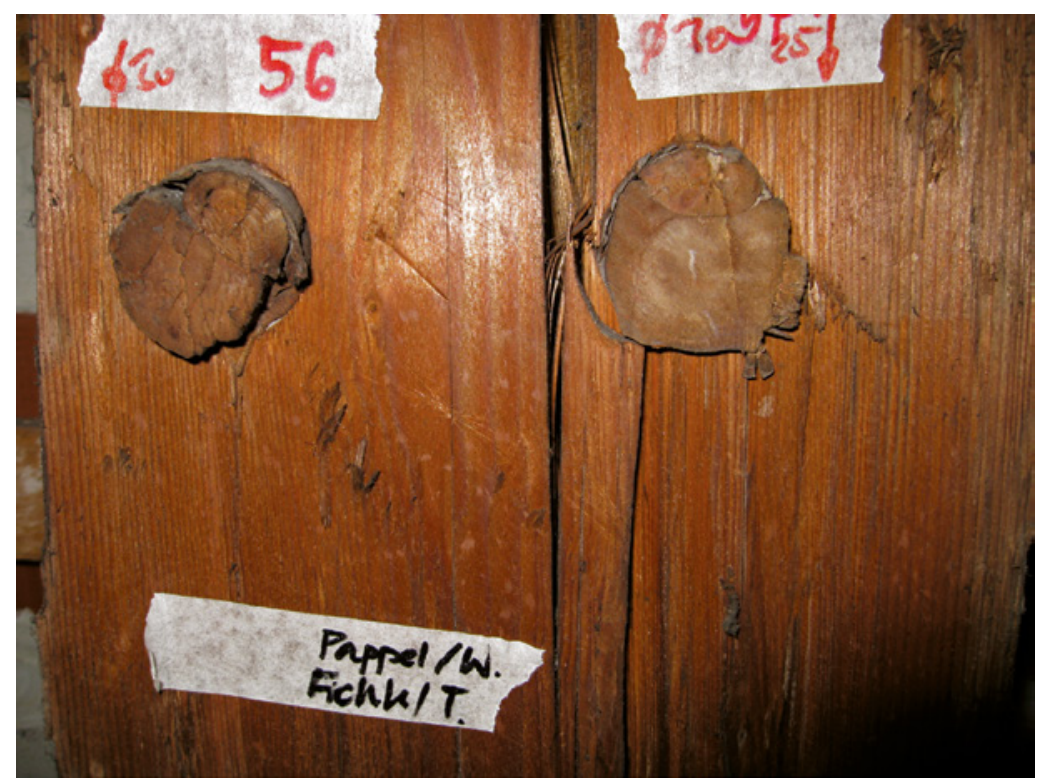

FIGURE 4 Round rafting wedges found in the timber of the roof construction of the Amalienburg, Vienna castle. A 30-millimetre hole was drilled prior the insertion of the wedge (in this case poplar/willow) and the branch (upper part) as binding material (in this case spruce/fir). 


\begin{tabular}{llllll}
\hline Chronology & Region & Overlap & Glk & TvBP & TvH \\
\hline KalAA & Reichraminger Hintergebirge & 61 & 83 & 6.8 & 8.2 \\
AvnAA & Northern alpine foothills & 61 & 82 & 7.4 & 8.8 \\
SDAA & Southern Germany & 61 & 81 & 6.1 & 7.2 \\
AlpAA & Alpine region & 61 & 67 & 4.1 & 4.1 \\
WwwAA & Weinviertel region & 61 & 77 & 3.6 & 4.4 \\
\hline
\end{tabular}

Fir series from the Amalienburg (Vienna castle) dated 1692 compared to different small-scale regional chronologies. Glk, Gleichläufigkeit; TvBP, $t$-value Baillie-Pilcher; TvH, $t$-value Hollstein.

an example from the Amalienburg). This proves that the timber was not taken from the surroundings of Vienna, but was rafted. More than 425 dated samples from the roof construction of the Hofburg were analyzed using the method of dendro-provenancing. These samples were cross-dated against various smallscale regional-chronologies to find the most likely origin. Using this method, most of the samples were allocated to "Alpenvorland Nord" (the northern foothills of the Alps) and to the chronologies from the Reichraminger Hintergebirge (described above; Grabner et al. 2004, 2014, Wächter 2012). Timber from the Vienna Castle was found to not originate in Eastern Austria (see Table 1).

When scanning the archives of the "Finanz und Hofkammer" (Österreichisches Staatsarchiv; ÖStA, AVAFH KA, NÖHA, K. 229, 230) and those from the seigneury of Steyr (OÖLA, Herrschaftsarchiv Steyr, K. 771), several requests for construction timber from the court of Vienna sent to the authority of Steyr were found - for example, one drafted in $1616 \mathrm{AD}$. This request was answered, promising that 27 rafts ("Schachadillenflöße") would leave for Vienna as soon as they would be able to get the wood from merchants (Herrschaftsarchiv Steyr).

Codex Austriaci (1689) defined the "Schachadillenfloß" as a raft originating in Steyr and transporting 15 logs of silver fir spanning a length of 8.5-9 Klafter (equivalent to $16-17 \mathrm{~m}$ ).

Around this time, $36 \%$ of the used construction timber in the Amalienburg (Vienna castle) was fir (Wächter 2012, 15). In 1691, around 8o Schachadillenflöße were ordered for ceiling constructions (Dippelbaumdecken) and two roof constructions (1200 logs). Analyzing the Amalienburg (a part of the Hofburg Castle), several wooden elements with the felling dates of 1693-1694 AD were 
dendrochronologically dated. These timbers could be attributed to the chronologies of the northern Alpine foothills and the Reichraminger Hintergebirge, proving the origin at Steyr (see Table 1). Unfortunately, the provenancing was not highly significant. Therefore, further analysis of the archives was conducted.

Since 28 April 1372, the citizens of Wels were allowed to trade in all kinds of wood and timber. All wooden goods approaching Wels from the river Traun and its tributaries had to be sold in Wels (Marschall 1954, 47; see Fig. 1). Even the requirements of the church itself, along with those of noble land owners, had to be stopped and sold in Wels. The only exception was the transport of wood and timber requested by the Vienna court. They were, due to toll-privileges ("Paßbriefe"), allowed to pass free of charge.

Most of the wood originated in the seigneury of Scharnstein (abbot of Kremsmünster) along the rivers Alm and Traun. Within this region, 83 saw mills were operating. The sawn timber as well as the logs had to be sold in Wels. The felled trees would be lying around in the forests for a year before they were sawn or floated to Wels. The floating of the rafts to Vienna took place in spring and carried on until St. Martin's Day (11 November). Unfortunately, no data on the number of felled trees per year is available. Only the inventory of the sawmills in the Almtal ( $1558 \mathrm{AD}$ ) gives some data on wood, which had to be sold in 1559 AD: 71312 logs, 2465 o boards ("Laden") and 310 rafts (12 400 logs; Marschall 1954, 51).

As mentioned earlier, rafts for the court of Vienna did not have to pay toll (Paßbriefe), therefore the number of rafts and logs per year is not known. However, in $1589 \mathrm{AD}$, the officers examining the incoming wood in Vienna counted (up to 29 August) over 111 associations of ten rafts each: 74 for Vienna (29.6 logs) and 37 (14.8 logs) for different places west of the city (Marschall 1954, 51). Unfortunately, it is not known for which buildings were these logs ordered.

Dendrochronological dating of the main roof construction of the Capuchin church in Vienna showed felling dates with bark rings between 1619 and $1621 \mathrm{AD}$. The chronologies used were, like Hofburg, allocated to the northern alpine foothills. Thus, the timber came to the river Danube. Archival analyses showed that Archduke Ferdinand payed 2000 Gulden on the 25th of 
June 1619 for construction timber to build a new monastery and a church for the Capuchins in Vienna (ÖStA, AVA FH KA, NÖHA W 61/B/22, fol. 45, 25 Juni 1619).

On 30 January 1622, the convent of the Capuchins asked for an allowance to bring 6-7 rafts ("Dillen") from the Steyr along Danube to Vienna (ÖStA, AVA FHKA, NÖHA W 61/B/22, fol. 63, 30. Jänner 1622). The laying of the foundation stone of the church by Emperor Ferdinand II (former archduke Ferdinand) took place on September 8, 1622 (AWK, Annales, I, p. 6, 7. - AWK, Protocollum, p. 5. - AWK, Akten, 7. Wien I, Nr. 140, 1701).

To summarize, the felling of the trees took place in the years 1619 to 1621 . The rafting of the logs to Vienna happened sometime after 30 January 1622, which coincides with the main rafting period between March and November (Keweloh 1985, 83). The year of completion of the church (or the roof construction) is not recorded, but should be around 1625 . The first part of consecration is known to have taken place in 1627 .

Why was the full amount of timber brought to the building site before the foundation was laid? Round timber (logs) were always processed in moist conditions (Grebe 1861, 51; Böhm 1911, 16-17; Sichler 1990, 123; Fischer-Kohnert 1999, 28; King and Lohrum 2000, 17). The same procedure was usual for further processes, such as manufacturing the joints. As soon as the beams were cut to length, the tenons and mortises made, each part was marked with red chalk or by hewing numbers or figures (in German, "Abbundzeichen"). Cracks from the drying of the wood and the numbered marks make it obvious that further processing also took place under moist conditions (Cramer 1986, 136; Fischer-Kohnert 1999, 29-30; King and Lohrum 2000, 23; Schaaf 2009, 171-171).

There are two hypotheses, which cannot be proven at this time:

(1) The amount of timber necessary to set up the stone building - the gantrywas so great that the logs were ordered at the beginning of construction.

(2) The further processing (making of joints) started simultaneously with the onset of construction.

Further analysis of historical literature about craft procedures as well as an analysis of the archives concerning these buildings is necessary to understand the phases of construction, and therefore the timing of felling, rafting, hewing, sawing and further processing.

\section{Conclusion and Outlook}

It was possible to set up tree-ring chronologies for different regions as a background for dendro-provenancing, especially for the Reichraminger Hintergebirge. Archival research revealed that wood from this region was ordered for the Vienna castle or the Capuchin church in Vienna. 
Its origin could be traced back with the help of dendro-provenancing. However, it is also known that wood was ordered from the region of Scharnstein (Welser merchants), which cannot be differentiated from the Reichraminger Hintergebirge by means of dendro-provenancing because of comparable climate and growth conditions.

There are clues that suggest the delivery of logs and timber from the region of Passau and along the rivers Lech and Isar to Vienna and even further to the east (Budapest). For example, Keeß $(1823,7)$ noted, "the best of the Norway spruce timber for Vienna comes from the Schwarzenberg-Forests, Bohemia; followed by Schwaben and Bavaria". Additional small-scale tree-ring chronologies and a collaboration with experts working in these regions must be set up to identify and differentiate the varied sources of the timber that entered Vienna in this era.

\section{References}

Begemann H. 1977. Was ist Holz. Eine Einführung in die Holzkunde. Deutscher Betriebswirte Verlag, Gernsbach.

Böhm T. 1911. Handbuch der Holzkonstruktionen des Zimmermanns mit besonderer Berücksichtigung des Hochbaues. Springer Verlag, Berlin.

Cramer J. 1986. Bundzeichen. Bauen mit Holz 3: 136-140.

Daly A. 2007. Timber, Trade and Tree-rings. A dendrochronological analysis of structural oak timber in Northern Europe, c. AD 1000 to c. AD 165o. Ph.D. thesis. University of Southern Denmark, Odense.

Delfs J. 1985. Die Flößerei in Deutschland und ihre Bedeutung für die Volks- und Forstwirtschaft. In: H.-W. Keweloh (ed.), Flößerei in Deutschland: 34-54. Konrad Theiss Verlag, Stuttgart.

Eckstein D., Wrobel S. 2007. Dendrochronological proof of origin of historic timber retrospect and perspectives. In: K. Haneca, A. Verheyden, H. Beeckman, H. Gärtner, G. Helle, G. Schleser (eds) TRACE - Tree Rings in Archaeology, Climatology and Ecology, Vol. 5: Proceedings of the Dendrosymposium Tervuren, 2007: 8-20.

Eißing T, Dittmar C. 2011. Timber transport and dendro-provenancing in Thuringia and Bavaria. In: P. Fraiture (ed.) Tree Rings, Art, Archaeology: 137-15o. Brepols, Brussels. Fischer-Kohnert B. 1999. Das mittelalterliche Dach. Michael Imhof Verlag, Petersberg. Grabner M., Wimmer R., Weichenberger, J. 2004. Reconstructing the history of logdrifting in the Reichraminger Hintergebirge, Austria. Dendrochronologia 21(3): 131-137.

Grabner M., Karanitsch-Ackerl S., Wächter E., Bolka, M. 2014. New regional chronologies for eastern Austria - a basis for dendro-provenancing and dendroclimatology. Poster at EuroDendro, September 8-12, 2014, Lugo, Spain. 
Graf von Sponeck C.F. 1825. Handbuch des Flosswesens. Meßlersche Buchhandlung, Stuttgart.

Grebe K. 1861. Die Forstbenutzung. Verlag von J.F. Baerede, Eisenach.

Jägerschmid, K.F. 1827. Handbuch für Holztransport und Floßwesen. Müllersche Hofbuchhandlung, Karlsruhe.

Keweloh H.-W. 1985. Vom Baum zum schwimmenden Dorf. Der Bau von Flößen. In: H.-W. Keweloh (ed.) Flößerei in Deutschland: 55-110. Konrad Theiss Verlag, Stuttgart.

King S., Lohrum B. 200o. Historische Dachwerke. Universität Stuttgart, Stuttgart.

Koller E. 1954. Die Holztrift im Salzkammergut. Verlag des Amtes der o.ö. Landesregierung, Linz.

Marschall H. 1954. Die "St.-Nicolaj-Zeche und Bruderschaft der bürgerlichen Flößer und Holzhändler" zu Wels. Jahrbuch des Musealvereines Wels, 1954: 43-8o.

Neweklowsky E. 1952. Die Schiffahrt und Flößerei im Raume der oberen Donau. 1. Band. Oberösterreichischer Landesverlag, Linz.

Neweklowsky E. 1959. Die Flößerei auf den alpinen Nebenflüssen der oberen Donau. Jahrbuch des Österreichischen Alpenvereins 1959: 111-138. Universitätsverlag Wagner, Innsbruck.

Neweklowsky E. 1960. Die Trift im alpinen Raum der oberen Donau. Jahrbuch des Österreichischen Alpenvereins 196o: 169-177. Universitätsverlag Wagner, Innsbruck.

Neweklowsky E. 1964. Die Schiffahrt und Flößerei im Raume der oberen Donau. 3. Band. Oberösterreichsicher Landesverlag, Linz.

Radkau J. 2007. Holz - wie ein Naturstoff Geschichte schreibt. Ökom Verlag, Munich.

Schaaf U. 20o9. Barocke Dachwerke in Schlesien. In: P. Zalewski, Paul (ed.) Dachkonstruktionen der Barockzeit. Michael Imhof Verlag, Petersberg.

Sichler J.G. 199o. Die Bamberger Bauverwaltung (1441-1481). F. Steiner, Stuttgart.

von Keeß, S.E. 1823. Beschreibung der Fabrikate welche in den Fabriken, Manufakturen und Gewerben des Österreichischen Kaiserstaates erzeugt werden. Zweiter Band. Anton Straß, Vienna.

Wächter E. 2012. Dendro-Provenienz am Beispiel des Konstruktionsholzes der Wiener Hofburg. Bakkaulareatsarbeit Universität für Bodenkultur Wien, Vienna.

Wächter E., Grabner, M. 2012. Dendro-provenancing - Results from the Vienna Castle (Hofburg). Poster at the Second Workshop on Historical Wood Utilization, Egmond aan Zee, Netherlands, September 28-30.

Wegener G. 2007. Holz - Multitalent zwischen Natur und Technik. In: M. Fansa, D. Vorlauf (eds) Holz-Kultur. Von der Urzeit bis in die Zukunft. Schriftenreihe des Landesmuseums für Natur und Mensch, Heft 47: 175-182. Phillip von Zabern, Mainz am Rhein.

Weichenberger J. 1994. Die Holztrift im Nationalpark Kalkalpen. Bericht im Auftrag des Vereins Nationalpark Kalkalpen. Molln. 
Wiesenhofer H., Wiesenhofer, F. 2015. Trift auf der Großen Erlauf. Erlauftaler Bildungskreis, Purgstall.

Ziethen G. 200o. Und ewig rauschen die Wälder - von den Holzvorkommen der Antike zum Raubbau an der Natur. In: Xylem und Phloem. Natur und Kulturgeschichte des Holzes: 65-78. Frankfurt am Main. 